\title{
Produk Furnitur dari Metal sebagai Pengembangan Teaching Factory Politeknik Bosowa
}

\author{
Ulia Ridhani ${ }^{1}$, Alang Sunding ${ }^{2}$, Imron Burhan ${ }^{3}$ \\ Program Studi Perawatan dan Perbaikan Mesin, Perpajakan, Politeknik Bosowa
}

\begin{abstract}
Furniture industry is a creative industry activity that is included in craft clusters which produce products that can be utilized by the community, government agencies and industry.Every home,officeand industry requires furniture ranging from simple to luxurious furniture. Thus, people who couldlookthis opportunityhavea chance to develop,especially if they are able to meet the customer needs.Metal furniture is furniture made from the main metal material which is hollow iron, L profile, plate strip which can be combined with other materials such as wood, rubber, multiplex, and plastic which are then of high artistic value.Metal furniture is still very possible to be developed because there is no business that focuses on making this product in Makassar.Therefore, this business is expected tobea pioneer in thedevelopment of teaching factory based on construction and welding of Bosowa Polytechnic.One of the furniture products is a cafe set table that is commonly used in cafes that can producea productthathasvaluesell.As forthe total production cost is Rp.804,300, -with the desired profit margin of $25 \%$ of production costs. The production system used is "make to stock"in whichcustomers are freeto design their own desired products.
\end{abstract}

Keywords: industry, cafe table, make to order metal furniture, teaching factory

\section{PENDAHULUAN}

Berdasarkan pada bahan bakunya, furnitur dapat terbuat dari kayu, logam, plastik, rotan dan bahan baku lainnya. Data Kementrian Perindustrian pada tahun 2011 menyatakanS bahwa produksi furnitur metal berkontribusi sebanyak $8 \%$ dari keseluruhan produksi furnitur Indonesia. Di tahun 2017 menurun menjadi 7\%. Data World Integrated Trade Solution menunjukkan bahwa perdagangan internasional furnitur berbahan baku metal memiliki kontribusi sebesar $22 \%$.

Bukan hanya kurang mampu berkiprah di pasar Internasional, di pasar dalam negeripun ternyata belumsepenuhnya dikuasai oleh produksi dalam negeri. Permintaan furnitur Indonesia yang saat ini mencapai Rp 10 triliun per tahun, hanya 55\%-nya yang mampu dipenuhi oleh furnitur produk dalam negeri. Sisanya sebanyak $45 \%$ masih dikuasai produk impor setara dengan $\mathrm{Rp} 4,5$ triliun-Rp 5 triliun, bahkan disinyalir pada tahun 2016 pangsa pasar asing naik menjadi 55\% dengan nilai impor menjadi Rp 5,5 triliun - Rp 6 triliun. Sangat ironis memang melihat perkembangan industri furnitur Indonesia. Pada tahun 2000 Indonesia merupakan negara eksportir terbesar ke-5 di dunia, menurun pada urutan ke 18 pada tahun 2013 dan bahkan hanya berada pada urutan ke 25 pada tahun 2015 dengan total nilai ekspor yang mencapai USD 1,81 miliar dari total ekspor furnitur dunia yang mencapai USD 240 milliar. Peringkat Indonesia sebagai negara eksportir ini jauh di bawah peringkat Vietnam yang berada di posisi ke-8 dan Malaysia di posisi ke17. Nilai ekspor furnitur Indonesia ini berada di urutan ke-21 produk ekspor Indonesia, lebih rendah dari tahun sebelumnya dengan ekspor sebesar USD 1,9 miliar. Koran Tempo 2017 menyatakan bahawa nilai ekspor furnitur Indonesia berbahan baku metal USD 43,7 juta (Zamroni, 2017).

Metal adalah material yang sangat banyak dimanfaatkan dalam berbagai sektor kehidupan yang bermanfaat bagi manusia. Metal juga sudah diperdagangkan mulai dari bahan mentah dan setengah jadi yang kemudian berkembang menjadi perdagangan aneka macam produk berbahan dasar metal. Salah satunya adalah pemanfaatan metal sebagai bahan utama pembuatan furnitur. Secara umum bahan utama pembuatan furnitur adalah kayu, namun seiring berkurangnya bahan baku 
kayu dan berkembangnya teknologi bahan, produsen furnitur mulai beralih menggunakan besi hollow untuk bahan furnitur. Selain itu konsep furnitur minimalis modern menjadi tren yang berkembang dikalangan masyarakat sehingga sedikit demi sedikit furnitur kayu mulai tergantikan dengan furnitur dari bahan besi hollow.

Bahan baku logam seperti stainless steel, kuningan, aluminium dan besi saat ini semakin banyak digunakan sebagai bahan baku untuk furnitur modern. Furnitur dengan bahan baku besi harus dicat atau diberikan lapisan luar supaya tidak berkarat, oleh karena itu bahan baku jenis stainless steel ataupun aluminium lebih banyak dimanfaatkan untuk bahan baku furnitur karena tidak memerlukan lapisan luar tambahan. Furnitur dengan bahan baku logam biasanya sangat kuat dan memiliki durabilitas yang lebih tahan lama. Pada umumnya dalam satu furnitur bahan baku logam dikombinasikan dengan bahan baku lainnya seperti kayu atau plastik. Furnitur dengan bahan baku logam dapat digunakan sebagai furnitur di dalam atau di luar ruangan. Industri furnitur berbahan dasar logam memiliki kinerja yang berfluktuasi bila dibandingkan furnitur yang terbuat dari bahan lain. Nilai produksi furnitur logam paling tinggi sebesar Rp 2.844 miliar pada tahun 2012 selama periode 2010 - 2014. Pada tahun 2010, nilai produksi furnitur logam mencapai Rp 2.248 miliar dan turun menjadi Rp 1.753 miliar pada tahun 2014. Gambar 1 menunjukkan kinerja industri furnitur logam Indonesia selama periode 2010-2014.

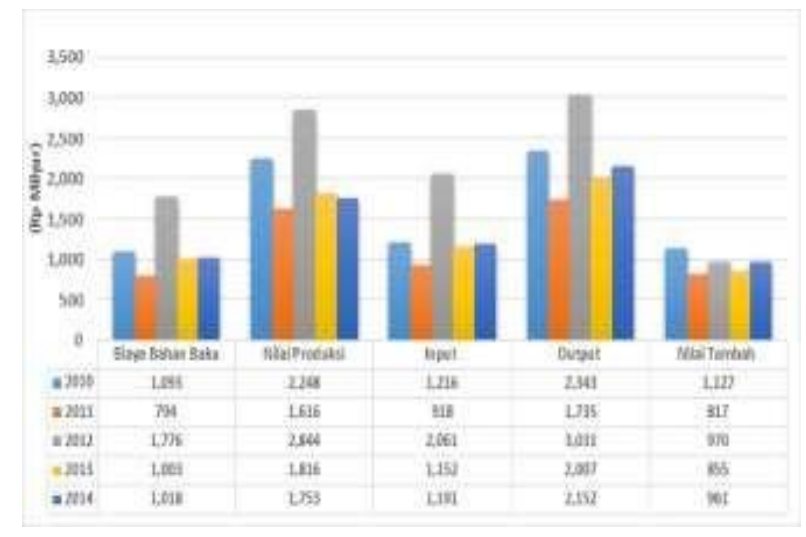

Gambar 1. Kinerja industri furnitur logam, 2010-2014
Hasil penelusuran beberapa di beberapa toko furnitur di Makassar menunjukkan bahwa furnitur dari bahan besi hollow sudah mulai diterima dimasyarakat karena selain harga yang ditawarkan lebih murah desainnya cukup minimalis sehingga cocok untuk kebutuhan perumahan yang berkembang saat ini.

\section{METODE PELAKSANAAN}

Sistem produksi yang diterapkan adalah Make to Order (MTO). Sistem MTO dimaksudkn untuk mencari keuntungan sebanyak-banyaknya ke arah pemuasan keinginan dan kebutuhan konsumen pada tingkat keuntungan yang memadai (reasonable). Sifat MTO yaitu konsumen membuat spesifikasi tentang produk yang diinginkan, selanjutnya produsen membantu pembeli untuk menyediakan spesifikasi tersebut dan kemudian produsen menentukan harga produk dan waktu pengiriman disesuaikan dengan permintaan pembeli (Sodikin, 2012). Berikut disajikan proses produksi yang diterapkan, yaitu:

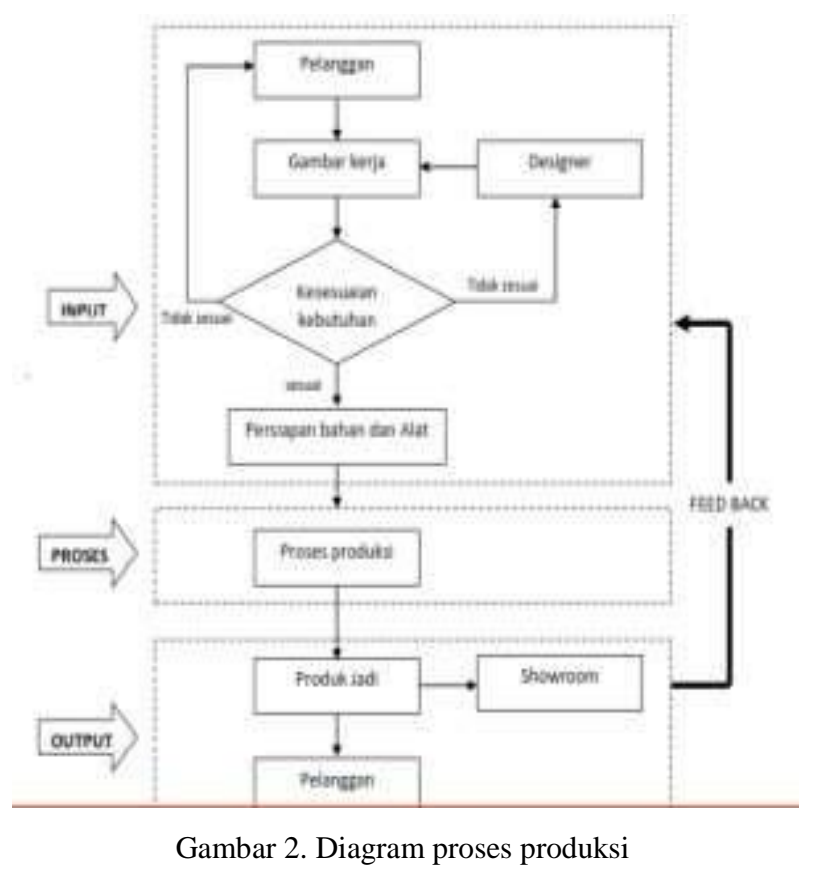

III. HASIL DAN PEMBAHASAN

Jasa pembuatan metal furniture mempunyai peluang yang besar untuk dikembangkan di Makassar, karena hampir seluruh produk furnitur 
dari bahan metal yang dijual di wilayah Makassar dan sekitarnya didatangkan dari Jawa untuk dipasarkan di wilayah Makassar dan sekitarnya. Belum ada usaha yang fokus menggarap usaha pembuatan furnitur dari bahan metal di Makassar. Keunggulan dari produk ini adalah pelanggan dapat menentukan model serta warna sendiri (custom order) sehingga produk benar-benar sesuai dengan keinginan pelanggan selain itu pelanggan diberikan kesempatan untuk melakukan konsultasi untuk mendapatkan produk yang paling sesuai dengan kebutuhan. Berbeda apabila pelanggan pergi ke toko furnitur, pelanggan harus memilih produk yang tersedia sehingga kadang-kadang model sesuai yang diharapkan tapi warna cocok dengan keinginan.

\section{A. Spesifikasi Produk}

Salah satu contoh produk adalah meja kafe set yang bahan rangka utama terbuat dari bahan metal yang dikombinasikan dengan multiplek kemudian difinishing dengan menggunakan cat duco atau dengan lapisan High Pressure Laminated (HPL).

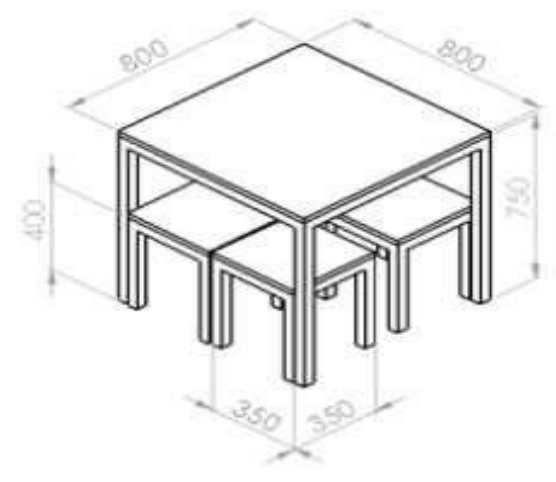

Gambar 3. Desain meja kafe

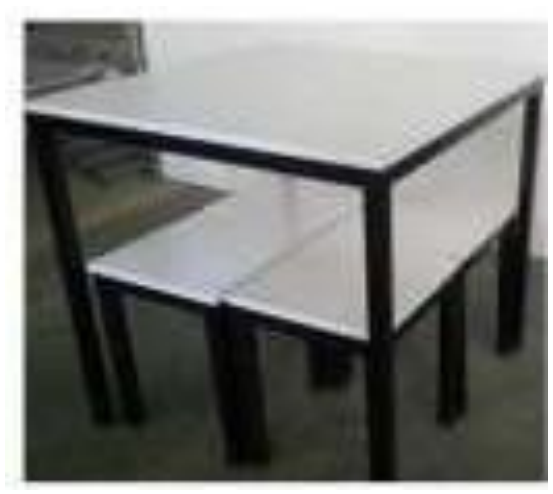

Gambar 4. Produk meja kafe

\section{B. Jenis-Jenis Biaya}

1. Biaya tenaga kerja

Biaya tenaga kerja adalah imbalan yang diberikan oleh kepada tenaga kerja yang dapat dinilai dengan satuan uang atas pengorbanan yang diberikannya untuk kegiatan produksi.

Tabel 1. Biaya tenaga kerja

\begin{tabular}{ccccc}
\hline Item & Jumlah & Satuan & $\begin{array}{c}\text { Harga satuan } \\
(\mathrm{Rp})\end{array}$ & $\begin{array}{c}\text { Biaya } \\
(\mathrm{Rp})\end{array}$ \\
\hline Pekerja & 18 & jam & 12500 & 225000 \\
\hline \multicolumn{5}{c}{ Sub Total } \\
\hline
\end{tabular}

2. Biaya bahan baku

Biaya bahan baku adalah biaya untuk bahanbahan yang dapat dengan mudah dan langsung diidentifikasikan dengan barang jadi atau bahan utama yang digunakan dengan proses produksi dan menjadi bagian utama dari produk jadi yang dihasilkan.

Tabel 2. Biaya bahan baku

\begin{tabular}{lcccc}
\hline \multicolumn{1}{c}{ Bahan } & Jumlah & Satuan & $\begin{array}{c}\text { Harga } \\
\text { satuan } \\
(\mathrm{Rp})\end{array}$ & $\begin{array}{c}\text { Biaya } \\
(\mathrm{Rp})\end{array}$ \\
\hline Holo 35 x 35 & 16,8 & $\mathrm{~m}$ & 15000 & 252000 \\
\hline Holo 20 x 20 & 0,735 & $\mathrm{~m}$ & 10000 & 7350 \\
\hline $\begin{array}{l}\text { Multipleks } \\
18 \text { satu sisi }\end{array}$ & 1 & $\mathrm{lbr}$ & 75000 & 75000 \\
\hline $\begin{array}{l}\text { Karet siku 40 } \\
\text { x 40 }\end{array}$ & 4 & buah & 2500 & 10000 \\
\hline Cat & 0,5 & $\mathrm{~kg}$ & 65000 & 32500 \\
\hline Tinner & 1 & $\mathrm{kali}$ & 5000 & 5000 \\
\hline Lem & 1 & $\mathrm{kali}$ & 5000 & 5000 \\
\hline Sekrup & 20 & $\mathrm{buah}$ & 250 & 5000 \\
\hline Edg & 3,2 & $\mathrm{mtr}$ & 6000 & 19200 \\
\hline Mata gerinda & 1 & $\mathrm{keping}$ & 10000 & 10000 \\
\hline Elektroda & 15 & $\mathrm{btg}$ & 550 & 8250 \\
\hline \multicolumn{5}{c}{} \\
\hline \multicolumn{5}{c}{ Sub Total } \\
\end{tabular}

3. Biaya overhead

Biaya overhead pabrik adalah biaya-biaya pabrik, selain bahan baku dan tenaga kerja langsung (Wauran, 2016).

Tabel 3. Biaya overhead

\begin{tabular}{ccccc}
\hline Item & Jumlah & Satuan & $\begin{array}{c}\text { Harga } \\
\text { satuan } \\
(\mathrm{Rp})\end{array}$ & Biaya (Rp) \\
\hline Listrik & 1 & paket & 100000 & 100000 \\
\hline Transportasi & 1 & kali & 50000 & 50000 \\
\hline \multicolumn{5}{c}{ Sub Total } \\
\end{tabular}




\section{Metode Penentuan Biaya Pokok Produksi (HPP)}

Metode penentuan biaya produksi adalah cara memperhitungkan unsur-unsur biaya ke dalam biaya produksi. Dalam memperhitungkan unsurunsur biaya produksi, terdapat dua pendekatan, yaitu:

1. Full costing adalah metode penentuan harga pokok produksi yang memperhitungkan semua unsur biaya produksi kedalam harga pokok produksi, yang terdiri dari biaya bahan baku, biaya tenaga kerja langsung, dan biaya overhead pabrik baik yang berperilaku variabel maupun tetap.

2. Variable costing adalah metode penentuan harga pokok produksi yang hanya memperhitungkan biaya produksi variabel, yaitu biaya bahan baku, biaya tenaga kerja, dan biaya overhead pabrik variabel (Patmaka, 2007).

Penentuan HPP menggunakan metode variabel costing yaitu dengan menghitung biaya bahan baku, tenaga kerja dan overhead yang digunakan. Berdasarkan hasil perhitungan sebelumnya diperoleh biaya pokok produksi sebesar Rp 804.300.

\section{Penentuan Harga Jual}

Harga jual adalah jumlah uang (ditambah beberapa produk kalau mungkin) mendapatkan sejumlah kombinasi dari barang beserta pelayanannya. Penentuan harga jual produk kami ditetapkan berdasarkan kenaikan margin yang ditentukan sendiri. Margin yang diharapkan adalah 25\% sehingga harga jual produk sebesar Rp 1.005.373

\section{E. Keunggulan Produk}

Jasa pembuatan metal furnitur mempunyai peluang yang besar untuk dikembangkan di Makassar, karena hampir seluruh produk furnitur dari bahan metal yang dijual di wilayah Makassar dan sekitarnya didatangkan dari Jawa untuk dipasarkan di wilayah Makassar dan sekitarnya. Belum ada usaha yang fokus menggarap usaha pembuatan furnitur dari bahan metal di Makassar. Keunggulan dari produk ini adalah pelanggan dapat menentukan model serta warna sehingga produk benar-benar sesuai dengan keinginan pelanggan. Selain itu pelanggan diberikan kesempatan untuk melakukan konsultasi untuk mendapatkan produk yang paling sesuai dengan kebutuhan. Berbeda apabila pelanggan pergi ke toko furnitur, pelanggan harus memilih produk yang tersedia sehingga kadang-kadang model sesuai yang diharapkan tapi warna cocok dengan keinginan. Keunggulan lainnya adalah dari segi keukatan. Produk sangat kuat karena terdapat rangka dari besi hollow yang membuat konstruksinya sangat kokoh.

\section{F. Tantangan Pasar}

Tantangan yang diperoleh dari program ini yaitu dalam proses pembuatan tentunya kita akan menemukan banyak tantangan mulai dari kualitas produksi sampai dengan kecepatan produksi sehingga inovasi perlu dilakukan untuk meningkatkan kualitas, memudahkan dan mempercepat proses produksi. Dari segi desain, produsen dituntut untuk mahir dalam desain 2 dimensi Produk sebelum dilakukan produksi mengingat produk yang dibuat berdasarkan keinginan pelanggan.

\section{G. Dampak Sosial Ekonomi}

Industri kreatif merupakan pilar ekonomi nasional maka produk ini juga dapat meningkatkan ekonomi masyarakat minimal wilayah kerja sekitar kampus Politeknik Bosowa. Sosial ekonomi secara signifikan akan terlihat apabila bisa berkembang dan dapat mempekerjakan tenaga kerja lokal yang selain bekerja diberikan kesempatan untuk belajar sehingga pekerja dapat memiliki kemampuan untuk mengembangkan usaha sendiri dan saling bermitra. Jaringan kerja diharapkan bisa tersebar ke beberapa daerah terutama wilayah Indonesia Timur sehingga dampak sosial ekonomi secara nasional yang dimulai dari Indonesia timur bisa tercapai melalui pemenuhan permintaan produk.

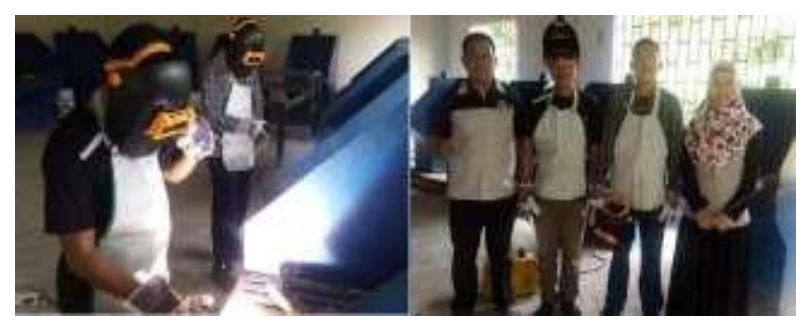

Gambar 5. Pelatihan pengelasan 


\section{H. Metode Analisis}

Metode analisis yang digunakan adalah metode analisis deskriptif, yaitu suatu metode yang dilakukan dengan cara mengumpulkan, menyajikan, serta menganalisis data sehingga diperoleh gambaran yang cukup jelas tentang masalah yang dihadapi, kemudian ditarik suatu kesimpulan sesuai keadaan yang sebenarnya.

\section{KESIMPULAN}

Pembuatan produk dari metal furniture merupakan peluang bisnis khususnya di Makassar karena belum adanya melakukan bisnis yang fokus pada metal furniture. Selain itu, kekuatan dari bahan baku seperti besi holo sangat membantu dalam hal konstruksi produk. Kegiatan lanjutan yang dapat dikembangan berupa pelatihanpelatihan pengelasan dengan tujuan untuk membentuk skill yang nantinya mampu membuka lapangan kerja sendiri yang kemudian ke depannya dapat dijadikan sebagai mitra kerja.

\section{UCAPAN TERIMA KASIH}

Ucapan Terimakasih kepada Direktorat Jendral Pendidikan Tinggi yang telah memberikan Hibah. Selanjutnya ucapan terimakasih kepada Direktur Politeknik Bosowa yang memberikan bantuan berupa mesin las mig sebagai pendukung proses produksi.

\section{DAFTAR PUSTAKA}

P. Zamroni Salim dan . 2017. Info Komoditi Furniture, Jakarta: Badan Pengkajian dan Pengembangan Perdagangan.

I. Sodikin dan A. Mashuri. 2012. "Penjadwalan Produksi pada Sistem Manufaktur Repetitive Make to Order Flow Shop Melalui Pendekatan Theory of Constrains," Jurnal Teknologi Technoscientia, vol. 4, no. 2, pp. $173-183$.

D. Wauran. 2016. "Analisis Penentuan Harga Pokok Produk dan Penerapan Cost Plus Pricing Method dalam Rangka Penetapan Harga JuAL pada Rumah Makan Soto Rusuk Ko' Petrus Cabang Megamas," Jurnal EMBA, vol. 4, no. 2, pp. 652-661.

I. S. R. Patmaka. 2007 . "Evaluasi Penentuan Harga Jual Produk Berdasarkan Metode Cost Plus Pricing," Universitas Sanata Dharma, Yogyakarta. 